\title{
Kurtz’s Last Words: A Vision for Redemption in Joseph Conrad's Heart of Darkness
}

\begin{abstract}
Hafsah Albarrak
Dammam University, Dammam, Saudi Arabia

The present study takes into cognition Edward Said's critical appraisal of Heart of Darkness in his book Culture and Imperialism. The present study will focus on two main points. Firstly, the imperial idea from the Eurocentric perspective the conventional image of imperialism as a redemptive force, unavoidable and inevitable in the dark world of Africa. Secondly, it also focuses upon what should never be shared "the waste and horror, of Europe’s mission in the dark world.”

Keywords: imperialism, Africa, Blacks, political narrative
\end{abstract}

This is the reason I affirm that Kurtz was a remarkable man. He had something to say. He said it. Since I had peeped over the edge myself, I understand better the meaning of the stare... wide enough to embrace the whole universe, piercing enough to penetrate all the hearts that beat in the darkness. He had summed up - he had judged. "The horror!"

(Conrad, 2009, p. 107)

\section{Introduction}

Joseph Conrad's Heart of Darkness has been mired in controversies ever since its publication in 1899. Readers and critics alike, have tried to impose/implicate extreme meanings to its text by analyzing it in context of dominant critical approaches — postcolonial, cultural, liberal, psychoanalytical.... Most commonly it has been implicated as a colonial text-racist and imperialist in content. At this point, I would like to assert, whatever reading prejudiced or unprejudiced, one may give to or its author-based mainly on a political premise, Heart of Darkness overwhelmingly presents a humanist concern. Definitely, the novel because of its political setting in a given historical moment, naturally elicits political points of view which coalesce with very many other perspectives. However, even then, it transcends above these base assumption to embrace an overall mantle of humanitarian/humanist cause and give it a universal moral vision. Even this perspective has been explored by the critic namely in a political context, but my aim is to focus on this moral concern by defining it through its most celebrated lines, Kurtz's last words “The horror! The horror!”-which transform his dying moment into an epiphanic instance for redemption, not only for his own self but for humanity at large.

Keeping in view, the stance of the two most notable writers and critics, Edward Said and Chinua Achebe, I

Hafsah Albarrak, Ph.D., Assistant Professor, English Department, Dammam University. 
will attempt to conceptualize the pedagogical and ideological perspective of the text in this light.

Joseph Conrad's Heart of Darkness, situated in a crucial and critical moment of history, is expressive of the historical force of imperialism, and draws attention to the "business of empire" as viewed by Edward Said (1994):

Conrad's realization is that if, like narrative, imperialism has monopolized

The entire system of representation—which is the case of Heart of Darkness

Allowed it to speak for Africans as well as for Kurtz and the other adventures,

Including his audience-your self-consciousness as an outsider can allow you

Actively to comprehend how the machine works, given that you and it are

Fundamentally not in perfect synchrony or correspondence. (p. 25)

The present study takes into cognition Edward Said's critical appraisal of Heart of Darkness in his book Culture and Imperialism. According to Said (1994), Conrad's narrative makes it possible to speak of the "Two Visions of Heart of Darkness" in the post-colonial world. Firstly, the imperial idea from the Eurocentric perspective - the conventional image of imperialism as a redemptive force, unavoidable and inevitable in the dark world of Africa. Secondly, it also focuses upon what should never be shared "the waste and horror, of Europe's mission in the dark world."

However, though commending Conrad for giving an ideological shift to the colonial discourse within the framework of the political narrative, Said (1994) writes :

Since Conrad dates imperialism, shows it contingency, records its illusions and Tremendous violence and waste...he permits his later readers to imagine something other than an Africa carved up into dozen of European colonies... he had little notion of what that Africa would be. (p. 26)

Said describes this as Conrad's "tragic limitation”; for his inability to imagine a world without imperialism or in other words, the inability of the natives to rule themselves. In fact at this juncture, one is reminded of Chinua Achebe's vitriolic outburst against Conrad for being a "bloody imperialist" in his famous speech at the University of Massachusetts in 1975. Chinua Achebe's (1988) description of Conrad was a racist, a liberal who hides behind a mask of tolerance. His protest was for unflattering portrayal of Africa and Africans as mere objects and the use of the tabooed word "N" in the novella. Though Achebe's indignation merits serious discussion, yet, to charge Conrad for hypocrisy, of his hiding behind a mask, in order to nullify his liberal sympathies is rather too biased and impressionistic. He fails to take into cognition the book's harsh criticism of the imperial machinery, its ruthlessness and savagery in the name of philanthropic enterprise. Furthermore, the Heart of Darkness voices an appeal to humanity: it makes a case for humanitarian and liberal ideals to be pursued and it does this through the lastwords of Kurtz—“The horror! The horror!” (Conrad, 2009, p. 104). In the extremelypoignant scene in the “ grove of death,” Marlow exclaims:

It was unearthly, and the men were- No, they were not inhuman...

But what thrilled you was just the thought of their humanity, like yours. (Conrad, 2009, p. 57)

Or

They were dying slowly — it was very clear. They were not enemies,

They were not criminals, they were nothing earthly now—nothing but

Black shadows of disease and starvation. (p. 29) 
Such a view encourages the readers to philosophize over the facts presented in the novella, in order to explore the human nature/psyche with its potential for evil and good, and to make a strong defense for its humanist concern.

Joseph Conrad's Heart of Darkness introduces us to a world marked by colonization/imperialism. The idea or the need for imperialism is foregrounded by the powerful image of darkness: darkness signifying the potential to be colonized. However, as the narrative unfolds, the meaning of darkness expands to connote it as a territory in itself: to become synonymous with evil. The evil inherent in man — this darkness of the soul which needs to be controlled, restrained or else will consume the man or thing animated by it. Marlow is saved by restraint whereas Kurtz is doomed by lack of it.

Conrad's liberal humanist concern can be best realized and appreciated in the context of the deafening whisper of the dying Kurtz — “The horror! The horror!” (Conrad, 2009, p. 106). Kurtz is described as aneloquent man, and the eloquence of his last words is enigmatic like the man himself: expressive of the very many shades of his being, yet powerful enough to engender multiple perspectives of meaning. The two visions underpinning Edward Said's analysis of Heart of Darkness are encapsulated and envisioned in these words of the protagonist Kurtz. In fact, a close reading of the text affords the reader, the knowledge of a vision — which is not merely political or cultural but humanistic. It transcends to the level of philosophical speculation concerned with the moral and spiritual reality of life and existence. It becomes a moral document having secular credentials to identify an ethical system that applies to humanity in general.

The horror of his life, a nightmare, is realized by the dying Kurtz and therein lies the vision of a possible future, of correction, of rectification—when and if realized—by mankind. The last words do not remain a dying confession of an evil man: they indeed become a goal, a moral vision, paving way to a more honorable and honest life-judicious, fair and liberal. A vision that embraces every walk of life. A mantra for redemption and salvation!

Conrad as a polish refugee had experienced and witnessed the duality, duplicity and diabolism of life: this he invests in his masterpiece Heart of Darkness.

This compelling narrative of Marlow's voyage into the heart of Africa, presents the reader with both the tragedy - the horror of colonial enterprise and the evil of human mind as well as the redemptive scope/vision about the human soul/existence embedded within the "horror" of Kurtz' exclamation at the time of his death. This realization of Kurtz becomes a clarion call for hope, not only for himself but also for Marlow the narrator, and mankind as well. It is no wonder that Marlow speaks of Kurtz to be a "remarkable man".

Conrad's Heart of darkness is based on his experience in Congo as recorded in his Congo diary. When Marlow, the narrator and alter ego for Conrad, makes his journey up to Congoriver, he becomes conversant with idea of evil as witnessed through the machinations of imperialism. Travelling up the river with the aim of relieving Kurtz at the Inner station, his journey assumes a symbolic dimension to posit an exploration of the human conscience to evoke moral responses. As the steamship moves towards Kurtz, the darkness within the human soul becomes an evident truth - a reality to be recognized, realized and hopefully rectified.

Marlow's voyagefrom the Outer station to the Central station and then onwards to the Inner station, exposes scenes of colonial violence, racism and inhumanity — a harsh picture of the hypocritical operations of the imperial enterprise. Conrad realized that the idea of imperialism was an illusion based on mythic rhetoric. In Heart of Darkness, he comments through Marlow: 
The conquest of the earth, which mostly means the taking it away From those who have a different complexion or slightly flatter noses Than ourselves, is not a pretty thing when you look into it too much What redeems it is the idea only. An idea at the back of it; not a Sentimental pretence but an idea: and an unselfish belief in the Idea - something you can set up, and bow before, and offer a Sacrifice to.... (Conrad, 2009, p. 14)

Thus, Conrad interrogates the self-ascribed civilizing mission—la mission civilisatrice offered by Europe (West/White/) for bringing the light of civilization to benighted people. The noble idea of the more powerful, more developed, and more civilized races in service of "civilization" ( and its economic benefits ) is revealed in context of the story. Philip Allingham (2015) cynically remarks at:

The fragile veneer of western civilization, the great white lie of the White Man's Burden with its implicit, pseudo-altruism, must be accepted if the natives of the dark continent are to be improved, enlightened, and transformed intowhite people with black skins. (p. 1)

Marlow's narrative moves backward and forward, incorporating scenes of "waste and horror, of Europe's mission in the dark world" (Said, 1994, p. 23) to mock the real motives of European imperialism in Africa. "The European idealist, believing the lies of his company and of the economic imperialism that supports it, is unprepared for the test of the character that the Congo imposes, and succumbs to the potential for the diabolical latent within every human consciousness" (Allingham, 2015, p. 1). The evil inherent in the Company's activities in Africa is satirically expressed in terms of "pioneers of progress", "emissaries of light”, and "pilgrims"; a direct condemnation of King Leopold's II brutal exploitation of the cultural and economic resources of Africa and the barbaric acts against the natives. Conrad (2009) makes plain the moral bankruptcy of the Company, whose headquarters at Brussels, reminded Marlow of "a city that always makes me think of a whited sepulcher” (p. 18).

In the words of Zelinck, "In this 'merry dance of death and trade', from 'the French warship lobbing shells into the jungle', to the 'Grove of Death' where Africans laborers expire, to the random gunplay directed at the locals...", the obituary is written by Kurtz, the megalomaniac — to "Exterminate the brutes". He uses the skulls of the natives as "nobs" to ornament the fencing of his hut at the Inner station (Victorian Web). Conrad makes Marlow, the protagonist narrator, a witness to this imperial savagery and brute force. He is disgusted by the money lust of the Company officials "hollow men molded to corporate delusions, corpulent pioneers, wheezing on dense jungle trails, dreaming of advancement while they collapse...the flabby devil” who operate the imperial machinery to further their own careers. "The Europeans disregard both the native's interest and their own morals well-being as they monopolize the ivory trade. The very air seems to sigh 'ivory', and the only earthly reason Europeans in the Congo can give for being out there is 'To make money of course'” (Allingham, 2015, p. 1).

At the Inner station, Marlow comes face to face with "evil” in the person of Kurtz himself. Empowered with authority, he gives expression to "his own base passions and atavistic drives" ( Allingham, 2015, p. 1). From an emissary of light, he becomes a monster of darkness. As a white man, endowed with imperial power, he is exposed to the evil of passion in all forms — greed, power, authority, selfishness... Lack of restraint changes his initial altruistic notions to the darkmalevolent intentions of his demonic self. To suppress, oppress and 
exterminate the "brutes" (Africans) becomes the law of his existence. According to Marlow, "All Europe contributed to the making of Kurtz” (Conrad, 2009, p. 77).

The book is cloaked in an all pervading darkness —England, Brussels, Africa. In this context "darkness" becomes connotative of the inability to see - a fundamental frailty of human condition; a failing to understand other human beings or to establish, sympathetic and amicable relationships with them. Kurtz' paintings of a "blindfolded woman" in the Brickmaker's cottage happens to signify this. But that was at the beginning, when Kurtz had arrived with his noble and philanthropic intentions, before the rot sets in him. However when he lies dying, his last words resonate with the implications of the unworthiness of his life as well as the human condition, of what man makes of man! His end makes him introspective, he begins to realize the meaning of life. He comprehends the unfortunate truth of human condition, its failing. Marlow perceives these last words as a reflection on a larger issue - the moral issue. They appear to echo, a self realization "a judgment upon the adventures of his soul upon the earth” (p. 106) at the personal level, and an attempt for the redemption of the human soul at the universal level. Marlow believes Kurtz to be successful because he does not run away from the truth.

Marlow understands that truth is the ability to judge oneself, to discover the reality of existence for the salvation of one's soul. Kurtz' coming to Imperial Congo, becomes his life's greatest undoing. Caught in the darkness of malicious conical bureaucracy, the evil of his malevolent self comes to the surface. It is through the imperial setting that Conrad/Marlow, explores the darkness within the human soul. Marlow in the narrative, examines the meaning of "horror" through various characters or agency(s) - Belgian Company, Company officials, "Eldorado" agents, and of course Kurtz himself. All are involved in the game of economic materialism and metaphorically in the game of life in context of the ethical values of good and evil. The uncontrollable passion for power and greed evoke evil in them. Buddha like, he muses upon the meaning of their actions in life and acts as a mediator, and a commentator to bring out the ethical intention and liberal sympathies of the author . and the best of it is evoked through the confessional words "The horror! The horror!"- a cry of an awakened soul!

The term "horror" in this epiphanic instance signifies the force which shapes character-restraint: lack of it prevents man to act wisely and judiciously and leads to his psychological disorientation, his doom! The text on restraint is significantly highlighted in context of the attitude of the African cannibals and European whites - Company officials, agents, Kurtz and Fresleven in testing times. Marlow in course of his journey, aboard the steamboat from the Central station to the Inner station is a witness to the cannibal crew act of restraint despite explanation for their restraint:

Why in the name of all the gnawing devils of hunger they didn't go for us - they were thirty to five — and have a good tuck-in for once, amuses me now when I think of it... Restraint! What possible restraint? Was it superstition, disgust, patience, fear,- some kind of primitive honour?... It takes a man all his inborn strength to fight hunger properly. And these chaps too had no earthly reason for any kind of scruple. Restraint! I would just as soon have expected restraint from a hyena prowling amongst the corpses of a battlefield. But there was the fact facing me... (Conrad, 2009, pp. 65-66) 
According to Daleski (1977), "The cannibal crew thus posit a capacity for the ultimate abandonment of utter savagery at the same time as they exemplify the innate restraint that Marlow considers the only effective safe guard of civilized behavior" (p. 65).

Marlow through his narration, effectively dismantles the western view of civilized behavior by making a case of the cannibals restraint contrary to Europeans' lack of it (Peter, 2008, p. 45). One of the greatest irony in the book is of Marlow getting a job with the Company as a result of this lack of restraint by the earlier steamboat captain Fresleven:

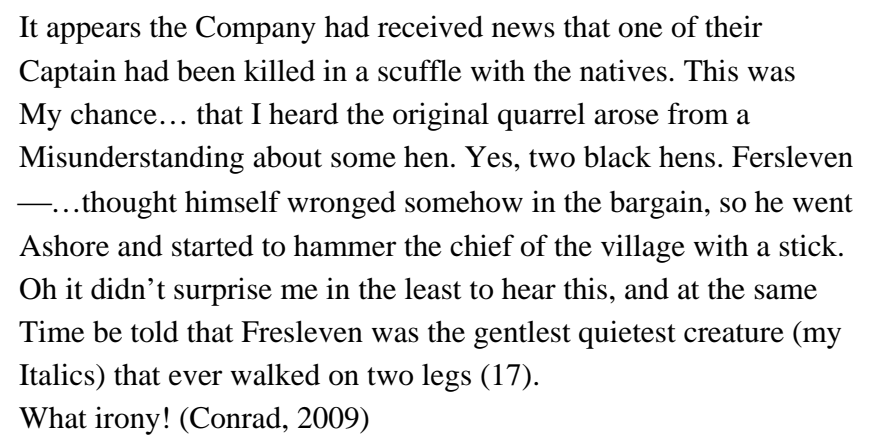

Thus, Conrad mocks at European Imperial bureaucracy and brute force unleashed on the natives in Africa. For in the language of the empire, those in the way are "enemies" and those who resist are "criminals".

Marlow's compelling narrative is connected directly with a redemptive force exposes the waste and horror of Europe's mission in the dark world as well as in human existence. In the words of Said (1994), Heart of Darkness "focuses not on what was shared in the colonial experience, but on what must never be shared, namely the authority and rectitude that come with greater power and development” (p. 25). As we read about Marlow's journey towards Kurtz "ivory trading empire" (p. 23) in the heart of Africa, Conrad wants us to see, how his great looting adventure becomes a metaphor for the assertive authority, aggressive power and inhumanity that a man (white) unleashes upon the less fortunate (natives/colonized ) people. This brings to one's mind, the agonized call of Wordsworth "What man has made of man” in Lines Written in Early Spring. As mentioned at the beginning, Edward Said acknowledges that in the novella, Conrad (2009) has recorded imperial illusions, its tremendous violence and waste, yet, he has permitted his readers to imagine something other than an Africa "craved" up of many smaller colonies; nevertheless he fails "to give us the sense that he could imagine a fully realized alternative to imperialism" which is politically feasible, "he had little notion” of what would take place when it came to an end (pp. 26-27).

Within the scope of the narrative, however, we observe that both Kurtz and Marlow acknowledge the meaning of "darkness", the former as he is dying and thelatter as he reflects introspectively on the meaning embedded in Kurtz' final words. This aspect posits an image of enlightenment-a moral vision for redemption. The "horror" of life's actions shame the truth of existence and encourage us, mankind, to work for a humanistic and secular ideal of togetherness/fraternity: "No eloquence could have been so withering to one's belief in mankind as his final burst of sincerity” (Conrad, 2009, p. 102). Marlow interprets Kurtz' last words as a self-refinement: a judgment upon the adventures of "soul” upon this earth. 
Kurtz' words are evocative of the unworthiness and evilness of his actions and are comment on life: an image both of human predicament and of his own experience. This allows for a more critical reading than merely of the imperial stereotype engendered by it. Heart of Darkness, is "based on a definite historical foundation andcontinuing predictive power for a moral and intellectual equilibrium” (Zelnick, 2015). The reading of the book highlights the European imperial mastery and authority over the natives, unrestrained and uncontrolled by humanistic ideals. The law defying Kurtz expressed it best when he said "exterminate all the brutes” (Conrad, 2009, p. 78). It is in these words lies the paradox of his last words, his confession: "The horror! The horror!”

Kurtz proves to be a dangerous man to the imperial design of the Company when alive and continues to do so in his death too. His “unsound methods" had threatened to expose the lie of the Company's benevolent design as well expose the evil that is latent in the heart of man (himself). He had come out with moral ideas to Congo, his sympathies were in the right place so as to be entrusted (by an International Society) with the humanistic mission of writing a report "Suppression of Savage Customs" (Conrad, 2009, p. 77) for future guidance of men. But when confronted with the vast and unbridled possibility of—lust, greed. Pride, power, and possession — of becoming a "god" to the natives, all his ideals get eliminated.

Marlow was fascinated by the change that came over Kurtz's face, moments before his death. It was as if a “veil had been rent" (Conrad, 2009, 106). Lying on his back with eyes closed, Marlow had heard him mutter "live rightly, die, die” (p. 105). He elucidates his observation thus:

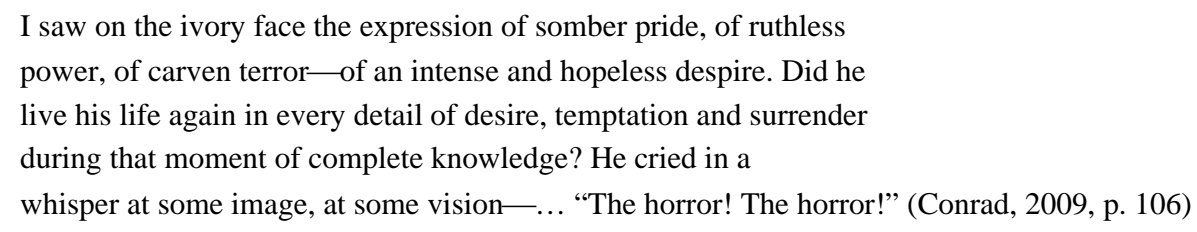

According to Marlow, the whisper was an expression of some belief, a conviction, "a vibrating note of revolt... the appalling face of a glimpsed truth- the strange coming of desire and hate...”" (Conrad, 2009, p. 107). Kurtz had made that last stride and stepped over the edge the invisible — to compress into that moment of time "all the wisdom, and all tritgh, and all sincerity”. For Marlow, his cry was much better, it was an affirmation, "a moral victory paid for innumerable defeats...” (Conrad, 2009, p. 108).

In the final section of the book, Marlow had expressed the impossibility of articulating the profundity of Kurtz's experience before death. Yet he does it, to the credit of both himself as the narrator and his justification of Kurtz as a "remarkable man”. In the enigmatic persona of Kurtz, he was able to discern his intelligence, honesty, an awakened conscience and the ability to judge than justify. He had lived his life with utmost conviction, even if it violated the conventional norms of acceptance. And even in his dying moments he had the courage to judge, to pass on a legacy, a vision to make Marlow and the readers ponder over the meaning of his last words, to awaken to truth of life, of moral existence.

\section{Conclusion}

The last words of Kurtz express the need for atonement which would lead to his own redemption and that of mankind. The journey of life is full of "deadly snags" that threaten to destroy it, make it hollow—reduce it to 
nothingness, if one is not conscientiously awake. The evocative richness of Conrad's language, of its narrative power, grants a poetic intensity to Kurtz' last whisper so as to make us (readers) repeat with Marlow:

The echo of his magnificent eloquence thrown to me (was) from a soul as translucently pure as a cliff of crystal. (Conrad, 2009, p. 108)

\section{References}

Achebe, C. (1988). Racism in Conrad's Heart of Darkness. London: Norton and Co..

Allingham, P. V. (2015). White lies and whited sepulchers in Conrad's Heart of Darkness. The Victorian Web. Lake Head University 2000. Web. 3/24 2015.

Conrad, J. (2009). Heart of darkness. New Delhi: Rupa.

Daleski, H. M. (1977). Joseph Conrad: The way of dispossession. London: Faber.

Peters, J. G. (2008). The opaque and the clear: The white fog incident in Conrad's Heart of Darkness (New ed.). H. Bloom, (Ed.). New York: Infobase Publishing.

Said, E. (1994). Culture and imperialism. New York: Vintage Books.

Zelinck, S. (2013). Conrad's bloody Imperialism: Achebe, Said, and what Conrad really wrote. Victorian Web.5 Sept, Retrieved from http://www.victorianweb.org/authors/conrad/zelnick.html 